\title{
Contribution of climate variability to occurrences of anoxic crises 'malaïgues' in the Thau lagoon (southern France)
}

\section{Influence de la variabilité climatique sur l'apparition de crises anoxiques ou 'malaïgues' dans l'étang de Thau (sud de la France)}

\author{
Ali Harzallah ${ }^{\mathrm{a}, *}$, Annie Chapelle ${ }^{\mathrm{b}}$ \\ anstitut national des sciences et technologies de la mer, 28, rue du 2-mars-1934, 2025 Salammbô, Tunisia \\ 'Ifremer, laboratoire DEL, BP 70, 29280 Plouzané, France
}

Received 4 September 2001; received in revised form 9 January 2002; accepted 9 January 2002

\begin{abstract}
The Thau lagoon, located in southern France, suffers episodically in summer from anoxic crises known as 'malaïgues'. Such crises mostly occur under warm conditions and low winds. In this paper we investigated effects of local weather conditions (air temperature, wind speed and precipitation over southern France), and two climate oscillations (the North Atlantic Oscillation and the El Niño-Southern Oscillation) on malaïgue occurrences based on 33-year data series and dates when malaïgues appeared. The study shows that the probability of occurrence of malaïgues increases with increasing temperature and decreasing winds in August both mostly associated to the high phase of an index of North Atlantic Oscillation. Malaïgues are found to be frequently preceded by increased precipitation in July which contributes to a larger nutrient input into the lagoon and to its eutrophication. It is also found that malaigues coincide with the warm phase of an El Niño-Southern Oscillation-like oscillation and are most significantly associated to values of this oscillation during the preceding May. This result is used to propose a simple method for an early warning of appearance of malaigues with a high degree of confidence. (C) 2002 Ifremer/CNRS/IRD/Éditions scientifiques et médicales Elsevier SAS. All rights reserved.
\end{abstract}

\section{Résumé}

La lagune de Thau au Sud de la France souffre épisodiquement en été de crises anoxiques connues sous le nom de «malaïgues ». Ces crises apparaissent le plus souvent quand la température de l'air est élevée et les vents faibles. On examine, dans cet article, les effets des conditions météorologiques locales (température de l'air, vitesse du vent et précipitation sur le sud de la France), et de deux oscillations climatiques (l'Oscillation Nord Atlantique et El Niño-Oscillation Australe) sur l'apparition des malaïgues, en se basant sur 33 ans de données. Les résultats montrent que la probabilité d'apparition des malaïgues augmente quand la température de l'air s'élève et la vitesse du vent diminue en août, les deux associées le plus souvent à la phase positive de l'Oscillation Nord Atlantique. Les malaïgues sont fréquemment précédées par une augmentation des précipitations en juillet, ce qui contribue à un apport de nutriments et à l'eutrophisation de la lagune. Nous avons aussi montré que les malaïgues coïncident avec la phase chaude d'une oscillation ayant les caractéristiques d'El Niño-Oscillation Australe et qu'elles sont associées, de façon significative, aux valeurs de cette oscillation durant le mois de mai qui précède. Ce résultat est utilisé pour proposer une méthode simple de prédiction des malaïgues avec un haut degré de confiance. (C) 2002 Ifremer/CNRS/IRD/Éditions scientifiques et médicales Elsevier SAS. Tous droits réservés.

Keywords: Climate variability; Anoxic crises; Malaïgues; Thau; Lagoon

Mots clés: Variabilité climatique; Eutrophisation; Malaïgue; Thau; Lagune

\footnotetext{
* Corresponding author.

E-mail address: ali.harzallah@instm.rnrt.tn (A. Harzallah).
} 


\section{Introduction}

The Thau lagoon is located in southern France in the vicinity of the city of Sete (Fig. 1). The lagoon is a semi-confined ecosystem, with narrow openings to the Mediterranean sea. It is one of the most important shellfish production sources in southern France with 15000 tons of oyster production per year. This activity covers about one-fifth of the lagoon area mainly in its north and northwestern parts (Fig. 1).

Episodically in summer, the Thau lagoon suffers from anoxic crises known as 'malaïgues'. During such episodes a lowering of water oxygen is observed with development of centres of anoxia and production of hydrogen sulfide. White coloured waters indicate the presence of anaerobic bacteria processes resulting in a toxic zone for animals and vegetation. Anoxic episodes affect several Mediterranean lagoons such as Venise, Sacca di Goro and Orbetello in Italy (Cioffi et al., 1995; Pugnetti et al., 1992) or the lagoon of Tunis in Tunisia (Belkhir and Hadj Ali Salem, 1981). The first observed and officially documented malaïgue event was that of 1969. Subsequent episodes occurred in 1971, 1975, 1982, 1983, 1987, 1990, 1992, 1994 and 1997 (Hamon, 2001; Souchu et al., 1998). The anoxia appears generally in July-August along the coast in some local zones rich in organic matter and propagates rapidly invading larger areas of the lagoon. The generation of a malaigue is probably related to the degradation of high concentration of organic matter or algae in these zones or at the bottom of the

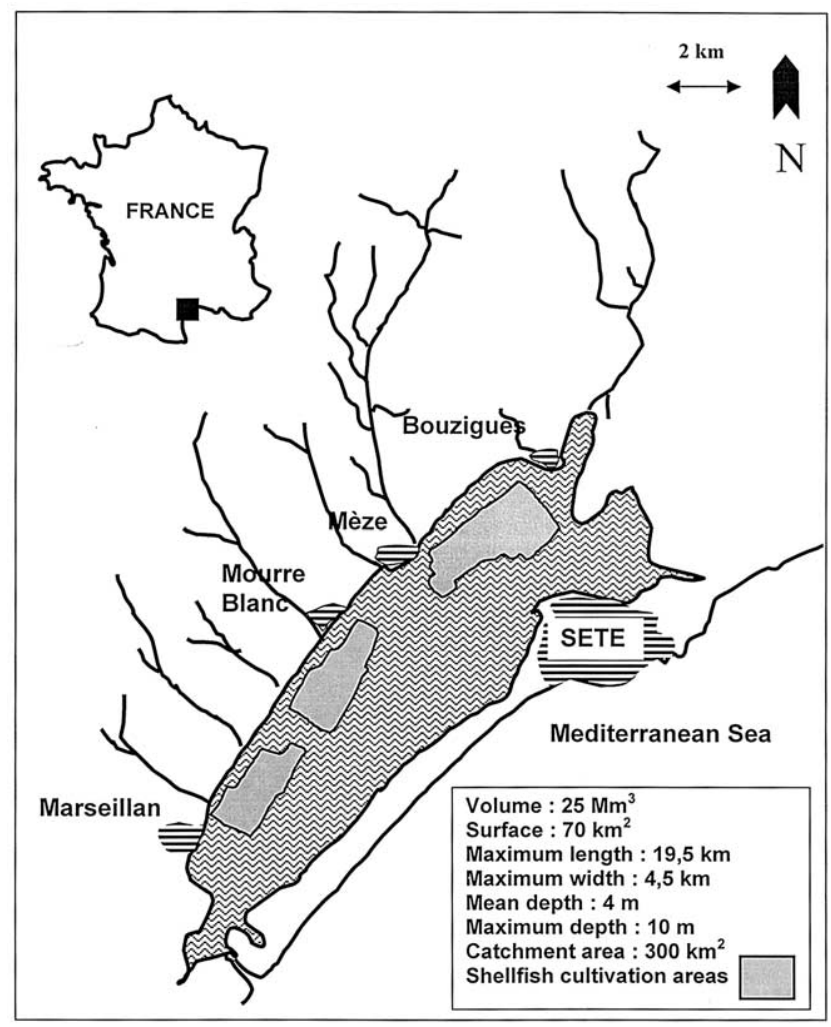

Fig. 1. Map of the Thau Lagoon. shellfish farming zones. Chapelle et al. (2001) successfully simulated the propagation of the malaigue using a numerical model but its generation is still not fully understood.

Malaïgue episodes are most frequently observed when atmospheric weather conditions are characterised by warm air temperatures lasting for several days or weeks together with a weakening of winds. These conditions decrease the oxygen exchange at the sea surface, water mixing inside the lagoon and water exchange between the lagoon and the Mediterranean. Furthermore, high sea temperatures enhance biological mineralisation and hence favour the appearance of anoxic crises. Delayed winter precipitation seasons with larger than normal precipitation in spring and early summer are also observed in malaïgue years which probably contribute to the input of nutrients into the lagoon through the several streams discharging into it. In situ measurements have shown that water salinity remains lower than normal during most malaïgue years (Hamon, 2001).

To our knowledge no quantitative studies of the role of weather conditions over southern France on malaïgues are performed. Simple inspection of dates of reported malaïgues shows that seven such episodes (1969, 1971, 1975, 1982, 1983, 1987 and 1997) almost coincided with the tropical ocean-atmosphere oscillation known as the El NiñoSouthern Oscillation (ENSO) (Walker, 1910; Bjerkness, 1966; Ropelewski and Halpert, 1987, 1989, 1996; Halpert and Ropelewski, 1992); only three episodes (1990, 1992 and 1994) did not coincide with ENSO. This result suggests a possible link between the two phenomena. Although ENSO impacts are mainly tropical, ENSO also affects extratropical latitudes (Kiladis and Diaz, 1989; Harzallah and Sadourny, 1995). The response of the atmosphere over the Europe-Mediterranean sector is shown to be weak. However, recent work revealed that ENSO may play a role in this area. Several studies (Oldenborgh et al., 1999; Moron and Ward, 1998; Kiladis and Diaz, 1989; Ward et al., 1999; van Loon and Madden, 1981; Fraedrich, 1990, 1993; Fraedrich and Müller, 1992; Fraedrich et al., 1992, 1993; Wilby, 1993) have linked weather types over Europe to ENSO. Although these studies did not permit to obtain a clear picture, they suggest a tendency for an increase of precipitation over the western Mediterranean, including southern Europe and northern Africa, in summer and autumn preceding the mature phase of ENSO and a tendency for a decrease of precipitation over the western Mediterranean in winter and spring following the mature phase of ENSO. These studies have shown significant patterns over the Europe-Mediterranean region but at present no physical mechanisms were found to explain them. In view of the simultaneous occurrence of malaigues and ENSO in seven episodes out of the ten reported and the above mentioned impacts of ENSO on local weather conditions over southern France, it is expected that ENSO may play a key role on the appearance of malaigues or on their enhancement. 
Local weather conditions leading to the appearance of malaïgues may also be related to the North Atlantic Oscillation (NAO) (Walker and Bliss, 1932; Kutzbach, 1970; Van Loon and Rogers, 1978; Wallace and Gutzler, 1981). The positive phase of NAO, corresponding to what is known as the high NAO, index is characterised by deeper than normal islanding low, enhanced westerlies and warm weather over northern Europe. Over the western Mediterranean the positive phase of NAO is characterised by high pressures leading to stable conditions and lowered precipitation. The negative phase of NAO (corresponding to low NAO index) is characterised by the opposite patterns with less stable conditions and increased precipitation over the western Mediterranean. The NAO exhibits a very low frequency (decadal) variability but also a large high frequency variability higher than that of ENSO. It is therefore expected that any effects will be almost simultaneous with the period of appearance of malaïgues. Most work on NAO was done for winter, the season of maximum variability of this oscillation. However NAO is also active in summer when its southern centre coincides with the Azores high.

The scope of the present paper is to investigate the possible effects of ENSO and NAO on the frequency of occurrence of malaïgues over the Thau lagoon and to present a method for their prediction. The data used are described in the following section. Section 3 shows results on possible links between malaïgue occurrences and local weather conditions, NAO and ENSO. In Section 4, a method to predict malaïgue occurrences is presented. The paper ends with some conclusions.

\section{Materials and methods}

As mentioned in the Introduction malaïgue dates used in this work are obtained from the Hamon (2001) report in which the state of the lagoon during each event is described. In general a malaïgue is declared when white colour is observed and is followed by shellfish mortality. Malaïgue dates considered here are: 1969, 1971, 1975, 1982, 1983, 1987, 1990, 1992, 1994 and 1997. For convenience and due to the lack of more precise information on dates of malaïgues, all of them are set to occur in August, the warmest month in the region with the most frequently observed malaïgue effects.

Data used for ENSO and NAO are respectively sea surface temperature (SST) monthly anomalies at the N3 region $(90 \mathrm{~W}-150 \mathrm{~W} ; 5 \mathrm{~N}-5 \mathrm{~S})$ from the NCEP extended data set and the NAO index monthly series (normalised surface pressure difference between centres at the western Mediterranean-eastern Atlantic and the Islanding low) from NOAA-NCEP CPC data, both for the 33-year period, 1967-1999. For local weather conditions we used monthly values of precipitation, wind speed and temperature for the same period and averaged over the region $(0-11 \mathrm{E}$; $39 \mathrm{~N}-50 \mathrm{~N}$ ). This set is obtained from diagnostic fields of the NOAA NCEP-NCAR CDAS-1 Climate Data Assimilation System I.

Data series (except ENSO series) are 3-month averaged by using a running mean to reduce the high frequency variability. The annual cycle is then removed from the series to retain only interannual variability. Finally, very low frequencies and tendencies are removed to avoid biases they eventually induce.

\section{Results}

\subsection{Links to local weather conditions, NAO and ENSO}

We first examine links between malaïgue occurrences and local weather conditions and then between malaïgue occurrences and global climate phenomena such as NAO and ENSO. However it is important to remember that local conditions may in turn be influenced by global phenomena. Hence the two types of link are not completely independent. The method used to investigate the links is the composite analysis. For a given variable, say ENSO, values of ENSO in August of the 10 malaiggue years are averaged. This average is tested against the zero mean using a Student's $t$-test. The same averaging method is then applied for the preceding (July, June, etc.) and following (September, October, etc.) months. This approach permits to examine the behaviour of variables before, during and after a malaïgue occurrence. It must be noted that using monthly averaged data, any time lag less than 1 month cannot be properly investigated.

\subsubsection{Links to local weather conditions}

The composite analysis for different lags is performed for air temperature, wind speed and precipitation series each averaged according to malaïgue episodes. The results are shown in Figs. 2-4, respectively. Composites for local air temperature (Fig. 2) show significant (at the 95\% level) positive anomalies in summer concomitant with malaïgue events with positive values reaching $0.6{ }^{\circ} \mathrm{C}$. For wind speed (Fig. 3), negative anomalies in summer (significant at the 95\% level) are concomitant with malaïgue events. Anomalies reach $-0.2 \mathrm{~m} \mathrm{~s}^{-1}$ in August. Variances of temperature and wind speed are much weaker in summer than in winter but these do not affect the results; most of the temperature series are positive and the wind speed series are negative in August. Composites for precipitation (Fig. 4) show that largest precipitation anomalies occur in July preceding a malaïgue. Values are not significant at the $95 \%$ level but one notices that for eight malaïgue events (out of the ten events considered), precipitation anomalies are positive in July with values larger than $0.2 \mathrm{~mm} \mathrm{~d}^{-1}$.

The results shown above confirm the weather conditions observed before or during malaïgues. Malaïgues are preceded by larger than normal precipitation and are associated with warmer than normal air temperatures and a reduced 


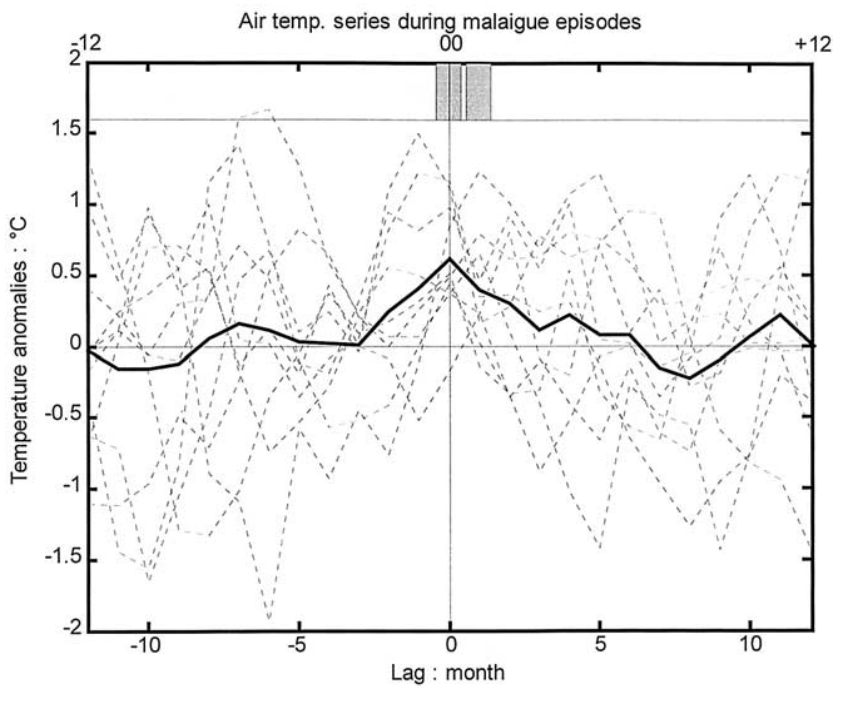

Fig. 2. Malaïgue composites of air temperature anomalies over southern France $(0-11 \mathrm{E} ; 39 \mathrm{~N}-50 \mathrm{~N})$. Continuous line: Composites of air temperature over the 10 considered malaïgues. Dashed lines: individual air temperature anomaly series used to calculate the composites. The abscissa corresponds to the number of months lagging (positive) or leading (negative) the month of August (zero) considered as the month when a malaigue appears. An abscissa of +3 corresponds to the month of November following the malaigue. Bars at the top of the figure refer to months when the composite is significant at the $95 \%$ level. Air temperature data are diagnostic fields of the NOAA NCEP-NCAR CDAS-1 Climate Data Assimilation System I. Time-period is 1967-1999.

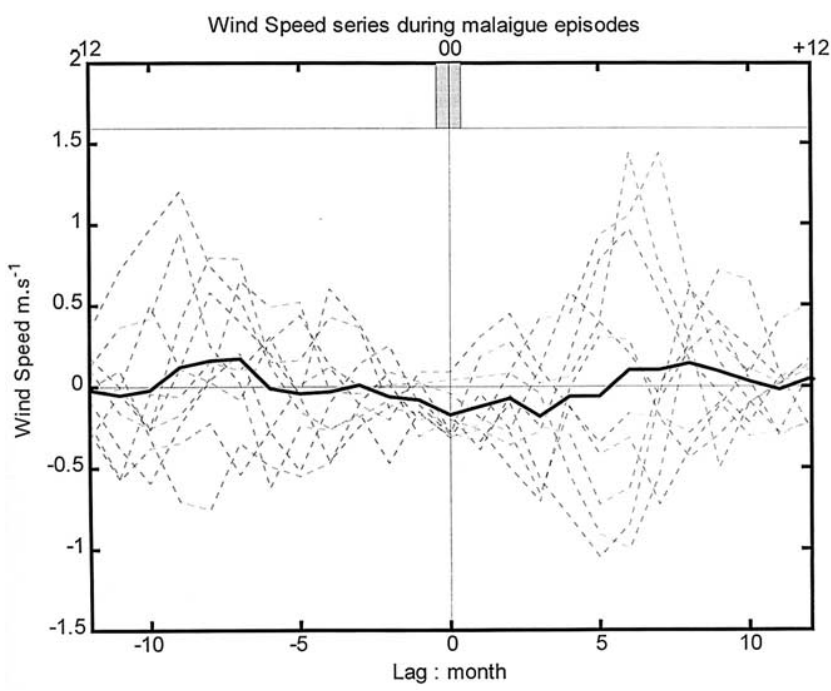

Fig. 3. As Fig. 2 but for malaïgue composites of wind speed anomalies.

wind speed. Such conditions favour eutrophication of lagoons as mentioned in the Introduction.

\subsubsection{Links to NAO and ENSO}

Composites for NAO are shown in Fig. 5. High and significant NAO index values (reaching 0.5) are found in August of malaïgue years. In addition, the NAO index is positive for nine malaïge events out of the ten considered. This analysis suggests that malaiggue occurrences are closely related to the NAO with most frequent events occurring

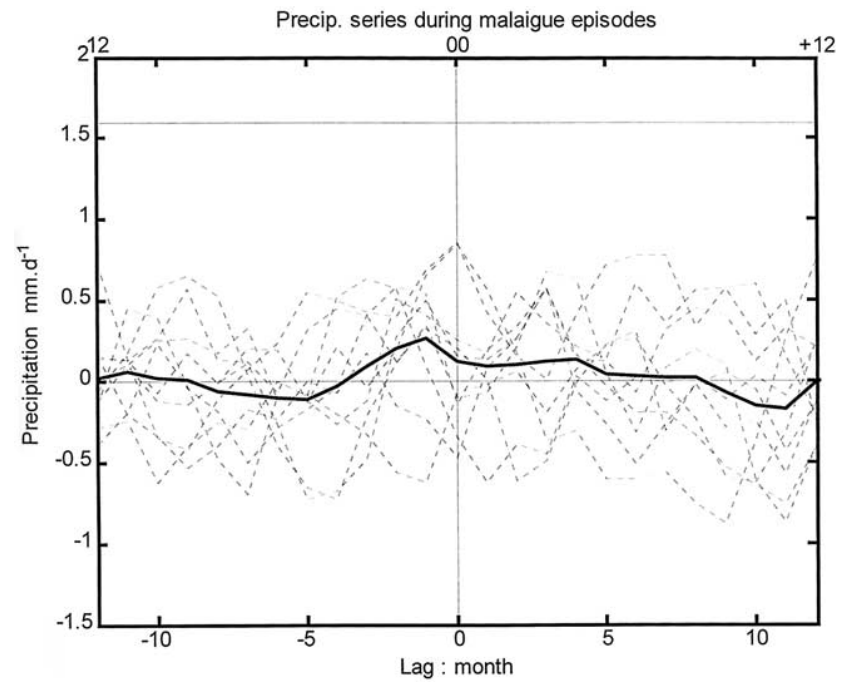

Fig. 4. As Fig. 2 but for malaïgue composites of precipitation anomalies.

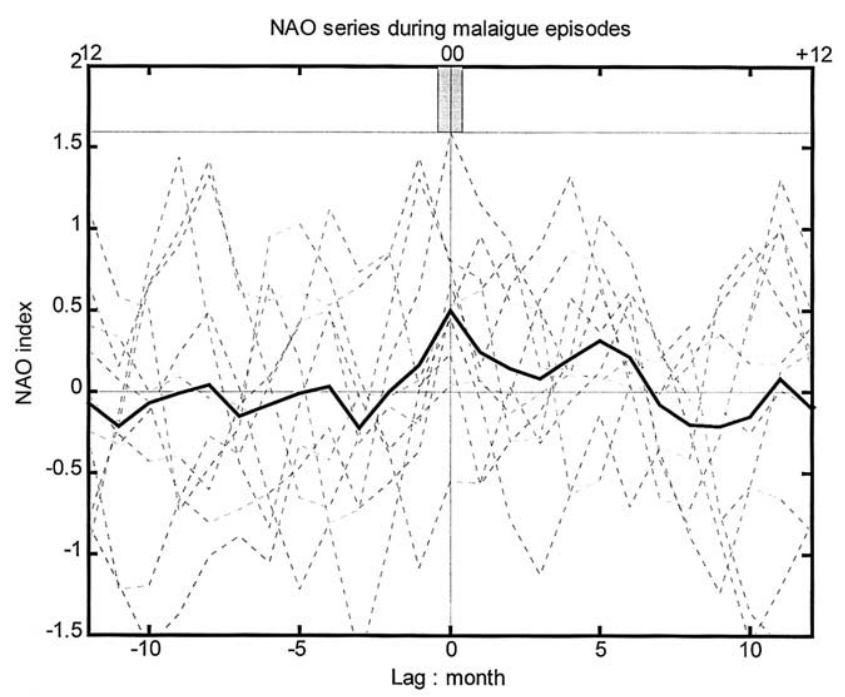

Fig. 5. As Fig. 2 but for malaïgue composites of the North Atlantic Oscillation index. The NAO index is from the NOAA-NCEP CPC data.

when the NAO index in August is high. This link probably reflects the effects of large scale circulation patterns associated to NAO on local weather conditions over southern France.

Additional composites are performed to examine such effects. In these composite time series of air temperature, wind speed and precipitation are composed according to the ten largest August NAO values in the data set. Results (not shown) show that high NAO values (high index) are associated with increasing temperature and decreasing wind speed in accordance with the results cited in the Introduction but based on the winter season. In contrast, no significant relationships were found for precipitation. The NAO probably affects the lagoon through its effect on local temperature and wind over southern France.

Composite analyses involving ENSO are shown in Fig. 6. The lag is extended to the previous and following 2 years to span an entire ENSO cycle. Malaïgue years are 


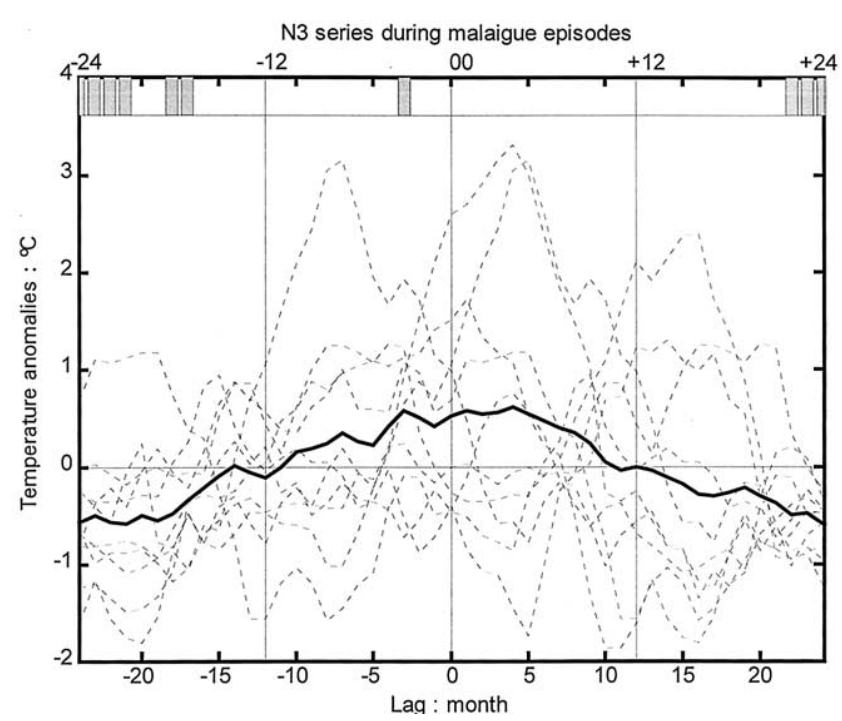

Fig. 6. As Fig. 2 but for malaigue composites of the sea surface temperature anomalies in the $\mathrm{N} 3$ region $(90 \mathrm{~W}-150 \mathrm{~W} ; 5 \mathrm{~N}-4 \mathrm{~S})$. N3 data is the NCEP extended index.

associated with an ENSO-like oscillation characterised by positive N3 SST anomalies lasting from the year preceding the malaïgue to the following one. For lags greater than 1 year SST anomalies are negative as in the ENSO typical behaviour. Composites are significant for lags greater than 1 year which may result from the biennial character of ENSO (Harzallah and Sadourny, 1997). Further investigations are needed to clarify causes of these significant values occurring at such large lags. The figure also shows that composites are significant in May preceding a malaïgue which reflects a relationship between N3 SST anomalies and malaïgues 3 months later.

ENSO events are phase-locked to the annual cycle: during a typical ENSO event, positive SST anomalies in the N3 region first appear in January-February, reach a maximum the following November-December and then decrease until the following Spring. Thus SST anomalies in May correspond to the increasing or decreasing phases of ENSO. Such phase-locking to the annual cycle is not evident in individual events shown in Fig. 6 but May, the month when composites are significant, corresponds to the increasing phase of the ENSO-like oscillation.

The significant composite values in May suggest that positive N3 SST anomalies of an ENSO-like oscillation influence malaïgue events occurring the next summer. The impacts of these anomalies on malaigues some months later may occur through atmospheric teleconnections or through surface temperature anomalies over other parts of the oceans that are associated to ENSO events. The full determination of mechanisms of the link between ENSO and malaïgues is beyond the scope of this paper.

Additional composite analyses are made to examine possible roles of ENSO on the local weather variables. In those composite time series of temperature, wind speed and precipitation are composed according to largest ENSO events in December, the month when ENSO reaches its mature phase. Results (not shown) show that the above mentioned positive precipitation anomalies in July are associated to ENSO with a significance higher than $95 \%$. As already shown in several previous studies ENSO and NAO are found to be uncorrelated.

The composite analyses using local weather conditions and global climate phenomena suggest that two distinct phenomena contribute to the appearance of malaïgues: the first is the NAO through its effect on temperature and wind speed. The contribution of NAO is expected in view of the well-known effects of the NAO on weather conditions over Europe and the Mediterranean. High NAO index in summer is associated with stronger high pressures, increased temperature and lowered wind speed. The second phenomenon contributing to the appearance of malaiggues is ENSO through its effect on precipitation over southern France in July and through other possible mechanisms.

The fact that ENSO contributes to malaïgue episodes is important. Indeed, it constitutes an additional confirmation to different studies attempting to demonstrate effects of ENSO on Europe and the Mediterranean sector. In addition it indicates that climate variability in the tropics may play an important role on small scale and distant ecosystems such as Mediterranean lagoons. Eventually, it will permit a prediction of appearance of malaïgues starting from May, the month the composites are significant at the $95 \%$ level.

\subsection{Malaïgue prediction}

In this section an early prediction of malaïgues is tested. The method is based on the links found between malaïgues in August and ENSO series in the preceding May. As no quantitative data on the strength of malaïgues are available, only information on the presence or the absence of a malaïgue event for a given year is used. To test malaïgue prediction, N3 SST anomalies in May are divided into intervals, $T-\Delta, T+\Delta$, with $\Delta$ fixed and $T$ spanning the range of the anomalies. For each $T$, the number of malaïgue cases (number of years when malaïgues occurred) is count $(p)$ and the number of no malaïgue cases (number of years when no malaïgues occurred) is count $(n) . n+p$ is the total number of years corresponding to N3 SST anomalies being inside the interval. The ratio $p /(n+p)$ is shown in Fig. 7 for all intervals. It represents the probability of appearance of malaïgues when SST anomaly is around T. A value of $\Delta=0.75^{\circ} \mathrm{C}$ is used; smaller or larger values lead essentially to the same results. The statistical significance of the probability shown in Fig. 7 is tested using probability of appearance of malaïgues only by chance. As ten malaïgue events occurred during the 33-year period studied, the probability of appearance of a malaiggue only by chance is $10 / 33=0.3$. Thus the probability of appearance of $p$ malaïgues only by chance form an ensemble of $n+p$ cases (the $n+p$ years inside the interval $[T-\Delta ; T+\Delta]$ ) is $P(p)=10 / 33^{p} 23 / 33^{n} C^{p}{ }_{n+p}$, where $C^{p}{ }_{n+p}$ is $(n+p) ! p !^{-1}$ 


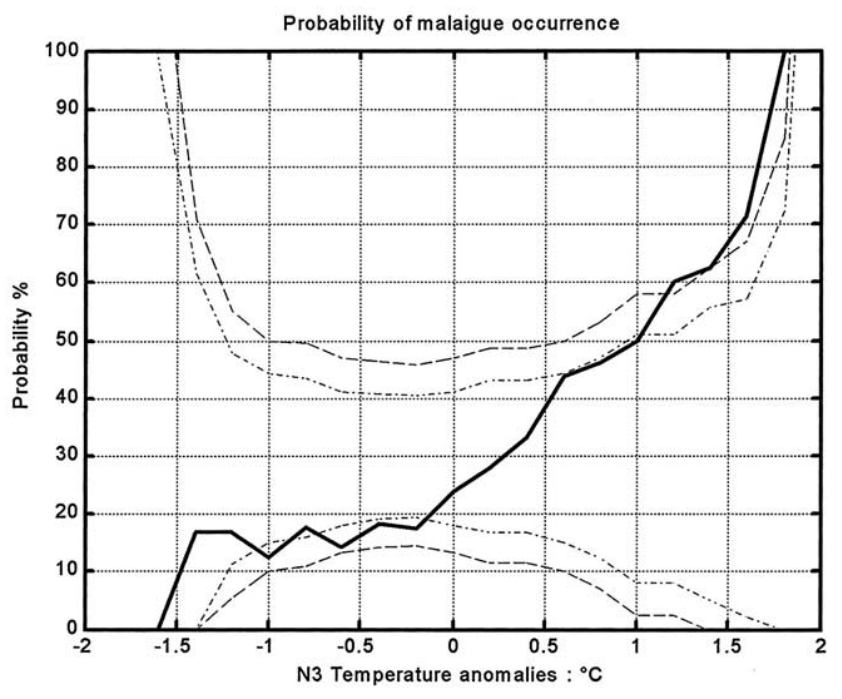

Fig. 7. Continuous line: Probability of appearance of a malaïgue as a function of the sea surface temperature anomalies at the N3 region (90 W-150 W; $5 \mathrm{~N}-5 \mathrm{~S}$ ). Dashed (dash-dotted) lines: upper and lower probability limits corresponding to $5 \%(10 \%)$ chance that a malaigue appears only by chance. Time-period is $1967-1999$.

$n !^{-1}$. Using this probability, values of $p$ ' corresponding to $P\left(p^{\prime}\right)=0.9(0.95)$ are calculated for all intervals. The corresponding values of the ratio $p^{\prime} /(n+p)$ are plotted in the same figure. They represent $10 \%(5 \%)$ probabilities that malaïgues occur by chance.

Fig. 7 shows that the probability of occurrence of malaïgues increases with increasing SST anomalies which confirms the above mentioned link between SST in May and malaïgue occurrences. The probability of appearance of malaïgues is less than $20 \%$ for negative SST anomalies. It is not significant for strong negative SST anomalies (stronger than $-1.2{ }^{\circ} \mathrm{C}$ ). This is due to such cases being very few in the N3 data set. The probability increases to $50 \%$ when SST anomalies reach $+1{ }^{\circ} \mathrm{C}$. This probability is higher than 70\% for SST anomalies higher than $1.5^{\circ} \mathrm{C}$. For SST anomalies stronger than $+1{ }^{\circ} \mathrm{C}\left(+1.2{ }^{\circ} \mathrm{C}\right)$ there is less than $10 \%(5 \%)$ chance that the high probability of appearance of malaïgues predicted by Fig. 7 is obtained by chance. The figure is therefore a simple and powerful tool permitting a prediction of appearance of a malaigue with a high degree of confidence. Suppose that for a given year the N3 SST anomaly in May is $+1.5^{\circ} \mathrm{C}$. The probability of occurrence of a malaigue the following summer, based on Fig. 7, is $68 \%$. This is much higher than the probability that one obtains without the use of prediction tools (30\%). For a N3 SST anomaly of $-1{ }^{\circ} \mathrm{C}$, the probability of occurrence of a malaigue is only $12 \%$, much lower than the random occurrence probability.

The same prediction method is performed for July values of precipitation $\left.\left(\Delta=0.5 \mathrm{~mm} \mathrm{~d}^{-1}\right)\right)$. Results are shown in Fig. 8 . The probability of occurrence of malaigues increases with increasing precipitation. It is high $(55 \%$, significant at the $95 \%$ ) for anomalies higher than $+0.7 \mathrm{~mm} \mathrm{~d}^{-1}$ and weak (less than 17\%) for negative anomalies stronger than $-0.2{ }^{\circ} \mathrm{C}$. For strongest positive and negative precipita-

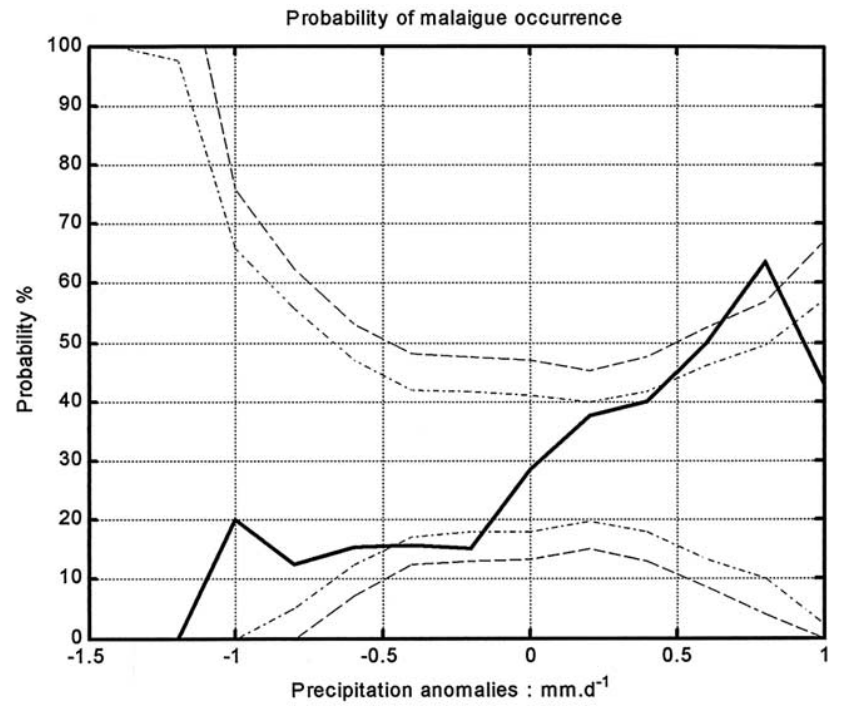

Fig. 8. As Fig. 7 but for the probability of appearance of a malaïgue as a function of precipitation anomalies over southern France (0-11E; 39 N-50 $\mathrm{N})$.

tion anomalies the probability is no longer significant. As for N3, this partly results from such cases being very few in the data set.

Although air temperature, wind speed and NAO cannot be used in an early prediction of malaïgues, we performed the same method to further examine their link. We used $\Delta=0.75$ for NAO, $\Delta=0.75{ }^{\circ} \mathrm{C}$ for air temperature and $\Delta=0.2 \mathrm{~m} \mathrm{~s}^{-1}$ for wind speed. The probability of occurrence of malaigues (not shown) increases with increasing NAO and temperature and decreasing wind speed. It is significant at the $90 \%$ or the $95 \%$ level for strong anomalies which clearly shows that weather conditions have significant impacts on malaïgues.

\section{Discussion and conclusions}

The relationship between recurrent malaïgues in the Thau lagoon and weather conditions over southern France, the NAO and ENSO are investigated in this paper. The study shows that the frequency of occurrence of malaïgues increases with increasing air temperature and decreasing wind speed in August. These weather anomalies are confirmed to occur mostly during high NAO index. Malaïgue occurrences are also shown to increase with increasing precipitation in July. This confirms observations and hypotheses of roles of rivers and streams discharging nutrients into the lagoon and hence contributing to its eutrophication. Malaïgue episodes are found to be associated with the positive phase (warm conditions) of an ENSO-like oscillation. This relationship is significant at the $95 \%$ level in May preceding the malaigue. This relationship is not always phase-locked to the ENSO evolution. Indeed, although most malaige events are associated to the onset phase of ENSO, some of them are associated to the decay phase. The 
increase of precipitation over southern France in July is found to be closely related to ENSO events. Such effects of ENSO on precipitation over some areas of Europe and the Mediterranean were demonstrated by several authors but no plausible mechanism was found. Some recent investigations suggest that SST south of eastern Asia may play a key role.

To complete the study other phenomena such as the amount and type of the discharge into the lagoon, the functioning of the lagoon including the effect of resources it contains as well as other anthropogenic effects must be taken into account. In addition water exchange and renewal occurring between the lagoon and the Mediterranean may play an important role. These phenomena need direct measurements of water fluxes due to their dependence on atmospheric pressure and winds and their variations. Although no rigorous information on the strength of malaïgues is available, an attempt to correlate the malaïgue strength, based on the available data of the dead biomass of cultivated oysters, with strength of ENSO was performed. It showed no significant results. The strength of malaïgues may therefore be more dependent on anthropogenic effects than on ENSO effects. In addition, since 1969 the lagoon ecosystem has changed (eutrophication then water treatment since 1975). This reinforces the impacts of anthropogenic effects on the lagoon ecosystem. ENSO phenomena could act as favouring the appearance of malaïgues.

The link found between malaïgue episodes and NAO poses the problem of the long-term variation of this oscillation. Indeed, in addition to the high interannual variability, NAO exhibits an important decadal variability which could influence the climate over western Europe and the western Mediterranean at this time-scale. A recent work by Tsimplis (2000) has shown that the observed increase of the NAO index from the 1960s to the 1990s has led to increased atmospheric pressure over the western Mediterranean. This shift will probably act to reinforce the occurrence of malaïgues. This is also suggested by the observed increase of the frequency of malaïgues: the last four ones all occurred in the 1990s. However this fact may also result from the higher anthropogenic effects on the lagoon.

The significant relationships found between malaïgues and ENSO in the preceding May have permitted its early prediction. We proposed a prediction figure where the probability of occurrence of a malaïgue is obtained directly from N3 SST values in May together with a measure of the reliability of the prediction. This may constitute an early warning tool to users of the lagoon.

The effects of the 3-month averaging of data and the removal of the very low frequency variability and of tendencies were tested by repeating the calculations using raw data. Results and conclusions remain almost the same except for more noisy figures. It must be noted that the calculations performed in this paper are based on the whole ensemble of available data. Additional investigations based on future events will be of important help; they will permit to test the robustness of the results on an independent set of data. Additional work is needed to better understand the mechanisms of links to NAO and ENSO and to investigate possible similar effects on other Mediterranean lagoons.

\section{References}

Belkhir, M., Hadj Ali Salem, M., 1981. Contributions à l'étude des mécanismes d'eutrophisation dans le lac de Tunis : évolution des paramètres physico-chimiques et biologiques. Bull. Inst. Nat. Sci. Techn. Océanogr. Pêche 8, 81-98.

Bjerkness, J., 1966. A possible response of the atmospheric Hadley circulation to equatorial anomalies of ocean temperature. Tellus 18 , 820-829.

Chapelle, A., Lazure, P., Souchu, P., 2001. Modélisation numérique des crises anoxiques (malaïgues) dans la lagune de Thau (France). Oceanol. Acta 24, S97-S97.

Cioffi, F., Di Eugenio, A., Gallerano, F., 1995. A new representation of anoxic crisis in hypertrophic lagoons. Appl. Math. Modelling 19, 685-695.

Fraedrich, K., 1990. European grosswetter during the warm and cold extremes of the El Niño Southern Oscillation. Int. J. Climatol. 10, 21-31.

Fraedrich, K., 1993. An ENSO impact on Europe? A review. Tellus 46A, 541-552.

Fraedrich, K., Müller, K., Kuglin, R., 1992. Northern hemisphere circulation regimes during the extreme of the El Niño Southern Oscillation. Tellus 44A, 33-40.

Fraedrich, K., Bantzer, C., Burkhardt, U., 1993. Winter climate anomalies in Europe and their associated circulation at $500 \mathrm{hPa}$. Clim. Dynam. 8, 161-175.

Fraedrich, K., Müller, K., 1992. Climate anomalies in Europe associated with ENSO extremes. Int. J. Climatol. 12, 25-31.

Halpert, M.S., Ropelewski, C.F., 1992. Surface temperature patterns associated with the Southern Oscillation. J. Clim. 5, 577-593.

Hamon, P.Y., 2001. Les malaïgues de l'étang de Thau. Rapport IFREMER/DRV. pp. 129.

Harzallah, A., Sadourny, R., 1995. Internal versus SST-forced atmospheric variability as simulated by an atmospheric general circulation model. J. Climate. 8, 474-495.

Harzallah, A., Sadourny, R., 1997. Observed lead-lag relationships between the Indian summer monsoon and some meteorological variables. Clim. Dynam. 13, 635-648.

Kiladis, G.N., Diaz, H.F., 1989. Global climatic anomalies associated with extremes in the Southern Oscillation. J. Clim. 2, 1069-1090.

Kutzbach, J.E., 1970. Large scale features of monthly mean northern hemisphere anomaly maps of sea level pressure. Mon. Wea. Rev. 98, $708-716$

Moron, V., Ward, M.N., 1998. ENSO teleconnections with climate variability in the European and African sector. Weather 53, 287-295.

Oldenborgh, G.J., Burgers, G., Tank, A.K., 1999. On the El Niño teleconnection to Spring precipitation in Europe. Available at: http://www.knmi.nl/ oldenbor/publ/oldenbor03.html.

Pugnetti, A., Viaroli, P., Ferrari, I., 1992. Process leading to dystrophy in a Po River Delta lagoon (Sacc Di Goro): Phytoplankton-macroalgae interactions. In: Vollenweider, R.A., Marchetti, R., Viviani, R (Eds.), Marine Coastal Eutrophication. Elsevier, Bologna, pp. 445-456.

Ropelewski, C.F., Halpert, M.S., 1987. Global and regional patterns associated with the ENSO. Mon. Wea. Rev. 115, 1606-1626.

Ropelewski, C.F., Halpert, M.S., 1989. Precipitation patterns associated with the high index of the Southern Oscillation. J. Clim. 2, 268-284.

Ropelewski, C.F., Halpert, M.S., 1996. Quantifying SO-precipitation relationships. J. Clim. 9, 1043-1059. 
Souchu, P., Gasc, A., Collos, Y., Vaquer, A., Tournier, H., Bibent, B., Deslous-Paoli, J.M., 1998. Biogeochemical aspects of bottom anoxia in a Mediterranean lagoon (Thau, France). Mar. Ecol. Prog. Ser. 164, 135-146.

Tsimplis, M.N., 2001. Forcing of the Mediterranean sea by atmospheric oscillations over the North Atlantic. Geophys. Res. Let. 28, 803-806.

Van Loon, H., Madden, R.A., 1981. The southern oscillation. Part 1. Global associations with pressure and temperature in northern winter. Mon. Wea. Rev. 109, 1150-1162.

Van Loon, H., Rogers, J.C., 1978. The seesaw in winter temperature between Greenland and northern Europe. Part I: General description. Mon. Wea. Rev. 106, 296-310.
Wallace, J.M., Gutzler, D.S., 1981. Teleconnections in the geopotential height field during the northern hemisphere winter. Mon. Wea. Rev. 109, 784-812.

Walker, G.R., 1910. Correlations and seasonal variations of weather. Mem. India Meteorol. Dep. T21, 22-45.

Walker, G.R., Bliss, E.W., 1932. World weather V. Mem. R. Meteor. Soc. 4, 53-84.

Ward, M.N., Lamb, P.J., Portis, H., El Hamly, M., Sebbari, R., 1999. Climate variability in northern Africa: understanding droughts in the Sahel and the Magreb. In: Navarra, A (Ed.), Beyond El Niño Decadal Variability in the Climate System. Springer-Verlag, pp. 119-140.

Wilby, R., 1993. Evidence of ENSO in the synoptic climate of the British Isles since 1880. Weather 48, 234-239. 